\title{
Electrochemical promotion of oxidative coupling of methane on platinum/polybenzimidazole catalyst
}

Petrushina, Irina; Bandur, Viktor; Bjerrum, Niels; Cappeln, Frederik Vilhelm; Li, Qingfeng

Published in:

Journal of The Electrochemical Society

Link to article, DOI:

$10.1149 / 1.1504455$

Publication date:

2002

Document Version

Publisher's PDF, also known as Version of record

Link back to DTU Orbit

Citation (APA):

Petrushina, I., Bandur, V., Bjerrum, N., Cappeln, F. V., \& Li, Q. (2002). Electrochemical promotion of oxidative coupling of methane on platinum/polybenzimidazole catalyst. Journal of The Electrochemical Society, 149(10), D143-D147. https://doi.org/10.1149/1.1504455

\section{General rights}

Copyright and moral rights for the publications made accessible in the public portal are retained by the authors and/or other copyright owners and it is a condition of accessing publications that users recognise and abide by the legal requirements associated with these rights.

- Users may download and print one copy of any publication from the public portal for the purpose of private study or research.

- You may not further distribute the material or use it for any profit-making activity or commercial gain

- You may freely distribute the URL identifying the publication in the public portal 


\title{
Electrochemical Promotion of Oxidative Coupling of Methane on Platinum/Polybenzimidazole Catalyst
}

\author{
I. M. Petrushina, * V. A. Bandur, N. J. Bjerrum, * F. Cappeln, and L. Qingfeng* \\ Materials Science Group, Department of Chemistry, Technical University of Denmark, Lyngby DK-2800, \\ Denmark
}

\begin{abstract}
The electrochemical promotion of catalytic methane oxidation was studied using a $\left(\mathrm{CH}_{4}, \mathrm{O}_{2}, \mathrm{Ar}\right), \mathrm{Pt} \mid$ polybenzimidazole ( $\mathrm{PBI})-\mathrm{H}_{3} \mathrm{PO}_{4} \mid \mathrm{Pt},\left(\mathrm{H}_{2}, \mathrm{Ar}\right)$ fuel cell at $135^{\circ} \mathrm{C}$. It has been found that $\mathrm{C}_{2} \mathrm{H}_{2}, \mathrm{CO}_{2}$, and water are the main oxidation products. Without polarization the yield of $\mathrm{C}_{2} \mathrm{H}_{2}$ was $0.9 \%$ and the yield of $\mathrm{CO}_{2}$ was $7.3 \%$. This means that $\mathrm{C}_{2}$ open-circuit selectivity was approximately $11 \%$. Open-circuit voltage was around $0.6 \mathrm{~V}$. It has been shown that the $\mathrm{CH}_{4} \rightarrow \mathrm{C}_{2} \mathrm{H}_{2}$ catalytic reaction can be electrochemically promoted at negative polarization and exhibits a clear "volcano-type" promotion behavior, meaning that there was a maximum promotion effect at a polarization of $-0.15 \mathrm{~V}$, or $0.45 \mathrm{~V}$ catalyst potential vs. a hydrogen electrode $\left(3.8 \% \mathrm{C}_{2} \mathrm{H}_{2}\right.$ yield). The catalytic rate enhancement ratio, $r\left(\mathrm{C}_{2}\right) / r_{\mathrm{o}}\left(\mathrm{C}_{2}\right)$, at this maximum was 4.2 . There was ${ } \mathrm{C}_{2} \mathrm{H}_{2}$ production at polarization $\geqslant 0.1$ and $\leqslant-0.3 \mathrm{~V}$. The yield of $\mathrm{C}_{2} \mathrm{H}_{2}$ decreased with decreasing temperature. Dependence of $\mathrm{CO}_{2}$ yield on polarization also showed a "volcano-type" behavior with maximum yield of $8.3 \%$ at $-0.15 \mathrm{~V}$ polarization. The catalytic rate enhancement ratio for $\mathrm{CO}_{2}$ production, $r\left(\mathrm{CO}_{2}\right) / r_{\mathrm{o}}\left(\mathrm{CO}_{2}\right)$, at this maximum was 1.1 , which means that this catalytic reaction is only slightly affected by the electrochemical polarization. This indicates that polarization especially affects the $\mathrm{C}_{2}$ selectivity of the catalyst. The obtained data was explained by the electrochemical production of Pt-H active centers at the electrolyte-catalyst-gaseous reactant interface $(\lambda \gg 1)$.

(c) 2002 The Electrochemical Society. [DOI: 10.1149/1.1504455] All rights reserved.
\end{abstract}

Manuscript submitted October 29, 2001; revised manuscript received April 18, 2002. Available electronically August 16, 2002.

The fact that a catalytic system often consists of an electronic and an ionic conductor makes it possible to use electrochemical techniques to study the nature of the promotion effect in catalysts. Application of galvanic cells with solid electrolytes for the study of catalytic phenomena was suggested by Wagner. ${ }^{1}$ It was found later, that the rate and selectivity of a catalytic reaction can be remarkably and reversibly changed by electrochemical polarization of the electronic conductive catalyst on the ionic conductive support. ${ }^{2}$ This phenomenon was discovered by Vayenas et al. and named the "NEMCA effect" (non-faradaic electrochemical modification of catalytic activity). ${ }^{2}$ The term "electrochemical promotion" was first proposed by Pritchard ${ }^{3}$ in his response to Vayenas's paper. ${ }^{2}$

The NEMCA effect has been demonstrated for more than 50 heterogeneous ${ }^{3-13}$ and one homogeneous ${ }^{14}$ catalytic reactions. Thus, for example, it was shown that $\mathrm{CH}_{4}$ oxidation to $\mathrm{CO}_{2}$ on the Pt/yttria-stabilized zirconia (YSZ) catalyst can be electrochemically promoted up to five times. ${ }^{4}$ In the case of $\mathrm{CH}_{4}$ oxidative coupling on $\mathrm{Ag} / \mathrm{YSZ}$ catalyst (with $\mathrm{C}_{2} \mathrm{H}_{4}, \mathrm{C}_{2} \mathrm{H}_{6}$, and $\mathrm{CO}_{2}$ as the products), the $\mathrm{CH}_{4}$ conversion increased about $30 \%$ after positive polarization of the catalyst, while $\mathrm{C}_{2}$ selectivity increased at negative polarization. ${ }^{4}$

According to Vayenas et al., ${ }^{4-6}$ the NEMCA effect can be described by the following parameters

The rate enhancement ratio

$$
\rho=r / r_{\mathrm{o}}
$$

and the enhancement factor

$$
\lambda=\left(r-r_{\mathrm{o}}\right) /(I / 2 F)
$$

where $r$ is the catalytic rate at current $I, r_{\mathrm{o}}$ is the open-circuit catalytic rate, and $F$ is Faraday's constant. In all studied cases of the electrochemical promotion $|\lambda| \gg 1$, and that was the reason why this effect has been called "non-faradaic."

Vayenas et al. ${ }^{4-6}$ explained the electrochemical promotion of a catalyst as an effect of changes in the work function, e $\Delta \Phi$ (e is the electron charge, $\Delta \Phi$ is change of the electron extraction potential), of the catalyst under polarization. The change of the electron extraction potential has been assumed to be equal to the applied polarization, i.e.

* Electrochemical Society Active Member.

$$
\eta=\Delta \Phi
$$

It was also suggested that this change in the work function is caused by spillover of the products of the charge transfer from the threephase boundary to the catalyst-gas interface. The change in the work function was measured using the Kelvin probe technique. ${ }^{4-6}$

However, it was found later ${ }^{9-11}$ that the work function change of catalysts with different morphology, measured by the use of a Kelvin probe, may be only a part of the applied polarization ${ }^{9,10}$ or does not change at all. ${ }^{11}$ Summarizing the results of Ref. 4-6 and $9-11$, one can agree with the assumption of Metcalfe ${ }^{10}$ that

$$
\Delta \Phi=\xi \eta
$$

where $\xi$ is a coefficient. Furthermore, one can also assume $0 \leqslant \xi$ $\leqslant 1$.

It is known that the electrochemical potential of an electron in a metal $\bar{\mu}_{\mathrm{e}}$ (Fermi level) is a sum of the chemical potential of the electron in the metal $\mu_{\mathrm{e}}$ and e $\phi$, where $\phi$ is the inner or Galvani potential. The Galvani potential is a sum of an outer (or Volta) potential $\Psi$ and a surface potential $\chi$. The work function of the electron, e $\Delta \Phi$, is equal to the electrochemical potential of uncharged metal $(\Psi=0),{ }^{15}$ i.e.

$$
\Delta \Phi=\Delta \mu+\Delta \chi
$$

and $\Delta \Psi \neq 0$ is the reason for the difference between $\Delta \Phi$ and $\eta$ (Eq. 4).

Taking into account the considerations described and the published data on the electrochemical promotion, ${ }^{2-14}$ we can define three types of electrochemical promotion depending on values of the faradaic current $(I)$ and $\lambda$

1. The electrochemical promotion effect is the charge-induced (electrostatic) change of the strength of chemisorptive bonds at the catalyst-reactant interface (CI-effect). The CI-effect is characterized by $I=0$. Charging of the electric double layer at the catalystsupport interface is the only result of the polarization of the catalyst. $\Delta \Psi \neq 0$ and $\Delta \Phi \neq \eta$.

2. The electrochemical promotion effect is induced by the electrochemical production of the catalyst promoters (EPP-effect). I $\neq 0 ; \lambda \gg 1 ; \Delta \Psi \approx 0 ;$ and $\Delta \Phi \approx \eta$. 




Figure 1. Setup for study of electrochemical promotion of catalytic methane oxidation.

3. The case of electrocatalysis is when reactant (or reactants) of a catalytic reaction are oxidized or reduced electrochemically. I $\neq 0, \lambda \approx 1$.

The CI-effect usually plays an important role in the electrochemical promotion of homogeneous catalytic reactions using noncatalytic electrodes. ${ }^{14}$ Most of the published cases of electrochemical promotion ${ }^{2-13}$ can be ascribed to the EPP-effect or mixed CI- and EPP-effects. Electrocatalytic reactions are used in many important technologies, e.g., fuel cells, water electrolysis, etc.

In the present research the electrochemical promotion of catalytic methane oxidation was studied using a

$\left(\mathrm{CH}_{4}, \mathrm{O}_{2}, \mathrm{Ar}\right), \mathrm{Pt} \mid$ polybenzimidazole $(\mathrm{PBI})-\mathrm{H}_{3} \mathrm{PO}_{4} \mid \mathrm{Pt},\left(\mathrm{H}_{2}, \mathrm{Ar}\right)$

fuel cell. ${ }^{16}$ The aim of this study was to create electrochemically a new alternative to the $\mathrm{CH}_{4}-\mathrm{CO}_{2}$ route for the catalytic reaction through the electrochemical production of $\mathrm{H}-\mathrm{Pt}$ active centers, i.e., using the EPP-effect.

The PBI- $\mathrm{H}_{3} \mathrm{PO}_{4}$ electrolyte was chosen because it is stable at temperatures higher then $100^{\circ} \mathrm{C}$, at which $\mathrm{CO}$ poisoning of the $\mathrm{Pt}$ catalyst is of little importance. ${ }^{16}$

\section{Experimental}

The setup for study of electrochemical promotion of the catalytic methane oxidation is given in Fig. 1. A carbon-supported Pt catalyst with $\mathrm{Pt}$ load around $0.5 \mathrm{mg} / \mathrm{cm}^{2}$ was used in the present investigation. ${ }^{16}$ The morphology of the catalyst and the structure of the three-phase (Pt-electrolyte-gas) boundary are given in Fig. 2. The electrolyte was $\mathrm{PBI}$ doped with $\mathrm{H}_{3} \mathrm{PO}_{4}$ The techniques of preparing the $\mathrm{PBI}\left(\mathrm{H}_{3} \mathrm{PO}_{4}\right)$ membrane electrolyte and the $\mathrm{Pt}, \mathrm{C} / \mathrm{PBI}$ $\left(\mathrm{H}_{3} \mathrm{PO}_{4}\right) / \mathrm{Pt}, \mathrm{C}$ assembly (the working electrode area is $5 \mathrm{~cm}^{2}$ ) were developed in our group as well as by others. ${ }^{17}$ Graphite plates with gas channels were used as holders and current collectors. Two aluminum end plates with attached heaters were used to clamp the graphite plates. Temperature was controlled by a homemade controller. Mass flowmeters (5850 S Brookssmart) and 0154 Brooks Instrument controllers were used to control the inlet gas composition. The outlet gas composition was measured by an on-line quadrupole mass spectrometer (QMS 421, Pfeiffer) with a secondary electron multiplier detector and a cross-beam ion source with a rhenium filament. The ionization voltage was $70 \mathrm{~V}$. The outlet gases were admitted to the mass spectrometer from the fuel cell through a $0.8 \mathrm{~mm}$ stainless steel capillary.

The mixture of methane and oxygen, diluted by Ar $\left(\mathrm{CH}_{4} / \mathrm{O}_{2} / \mathrm{Ar}=34 / 17 / 70 \mathrm{~mL} / \mathrm{min}\right)$, was used as a working mixture at one electrode, and hydrogen or hydrogen/argon mixture (usu-

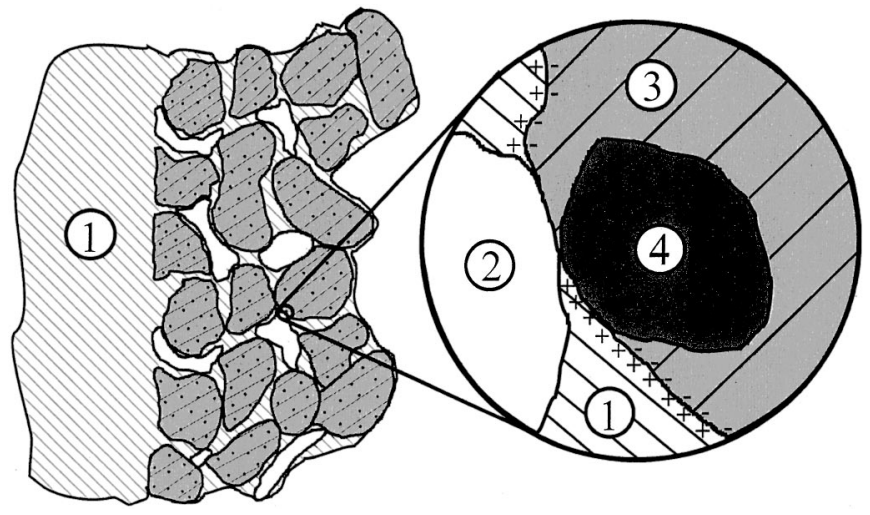

Figure 2. Reactant-catalyst-electrolyte boundary: (1) $\mathrm{PBI}-\mathrm{H}_{3} \mathrm{PO}_{4}$ electrolyte; (2) $\mathrm{CH}_{4} / \mathrm{O}_{2} /$ Ar gas phase; (3) carbon support of the Pt catalyst; and (4) Pt catalyst.

ally $\mathrm{H}_{2} / \mathrm{Ar}$ was $50 / 50$ vol\%) was used as reference and counter gas at the other electrode. The gas flow rate at both electrodes was 120 $\mathrm{mL} / \mathrm{min}$. The temperature was $135-137^{\circ} \mathrm{C}$.

Commercial gases $\mathrm{CH}_{4}(99.95 \%), \mathrm{H}_{2}(99.9 \%, \leqslant 10 \mathrm{ppm} \mathrm{O}$, $\leqslant 15$ ppm $\left.\mathrm{H}_{2} \mathrm{O}\right), \mathrm{O}_{2}\left(99.8 \% \mathrm{O}_{2}+0.2 \% \mathrm{~N}_{2}\right.$ and $\left.\mathrm{Ar}\right)$, and $\mathrm{N}_{2}(<40$ ppm $\left.\mathrm{O}_{2}+\mathrm{H}_{2} \mathrm{O}\right)$ were used.

An EG\&G Instruments (Princeton Applied Research) 283 potentiostat/galvanostat and homemade potentiostat controlled by 352 SoftCorr ${ }^{\mathrm{TM}}$ III software and homemade software were used for electrode polarization and steady-state voltammetric measurements. The initial (at zero polarization) catalytic activity was measured after the yield of gas products had stabilized, i.e., under steady-state conditions. For each value of polarization the measurements were performed after stabilization of the yield of gas products (1-1.5 h). Turnover frequency $v s$. polarization curves were reproduced for each studied product and temperature.

\section{Results and Discussion}

The results of the investigation of the electrochemical promotion of the catalytic methane oxidation are given in Fig. 3-7.

It has been found that $\mathrm{C}_{2} \mathrm{H}_{2}, \mathrm{CO}_{2}$, and water are the main oxidation products. Without polarization the yield of $\mathrm{C}_{2} \mathrm{H}_{2}$ was $0.9 \%$ (Fig. 3) and the yield of $\mathrm{CO}_{2}$ was $7.3 \%$ (Fig. 4). This means that $\mathrm{C}_{2}$ open-circuit selectivity was approximately $11 \%$. The open-circuit voltage $(\mathrm{OCV})$ was around $0.6 \mathrm{~V}$. The reactions are assumed to be

$$
\begin{gathered}
\mathrm{CH}_{4}+2 \mathrm{O}_{2} \rightarrow \mathrm{CO}_{2}+2 \mathrm{H}_{2} \mathrm{O} \\
2 \mathrm{CH}_{4}+3 / 2 \mathrm{O}_{2} \rightarrow \mathrm{C}_{2} \mathrm{H}_{2}+3 \mathrm{H}_{2} \mathrm{O}
\end{gathered}
$$

The oxidative coupling of methane (OCM) is a relatively widely studied catalytic reaction. ${ }^{18,19}$ However, in most OCM cases the major products are $\mathrm{C}_{2} \mathrm{H}_{6}, \mathrm{C}_{2} \mathrm{H}_{4}$, and $\mathrm{CO}_{2}$. It is also known that direct pyrolysis of methane to acetylene takes place at temperatures close to $2000^{\circ} \mathrm{C}$ with $30 \%$ methane conversion. ${ }^{20}$ An alternative route for direct conversion of methane into acetylene can be made through the activation in a two-stage burner by a hydrogen/oxygen flame. ${ }^{21}$ Thus, in an alumina reactor, acetylene can be produced from the preheated $\left(700^{\circ} \mathrm{C}\right) \mathrm{CH}_{4} / \mathrm{O}_{2} / \mathrm{H}_{2}$ gaseous mixture with a yield of $\sim 17 \%$. It was found in a recent investigation ${ }^{22}$ that the plasma catalytic conversion of methane produces acetylene with high selectivity and yield under atmospheric pressure in the temperature range $70-500^{\circ} \mathrm{C}$. The highest yield of $\mathrm{C}_{2}$ hydrocarbons (about $20 \% \mathrm{C}_{2}$ yield and more than $85 \%$ selectivity toward acetylene) was obtained in the hydrogen-containing plasma. Lower temperature favors the formation of acetylene, while no acetylene is formed at higher temperatures (more than $300^{\circ} \mathrm{C}$ ). 


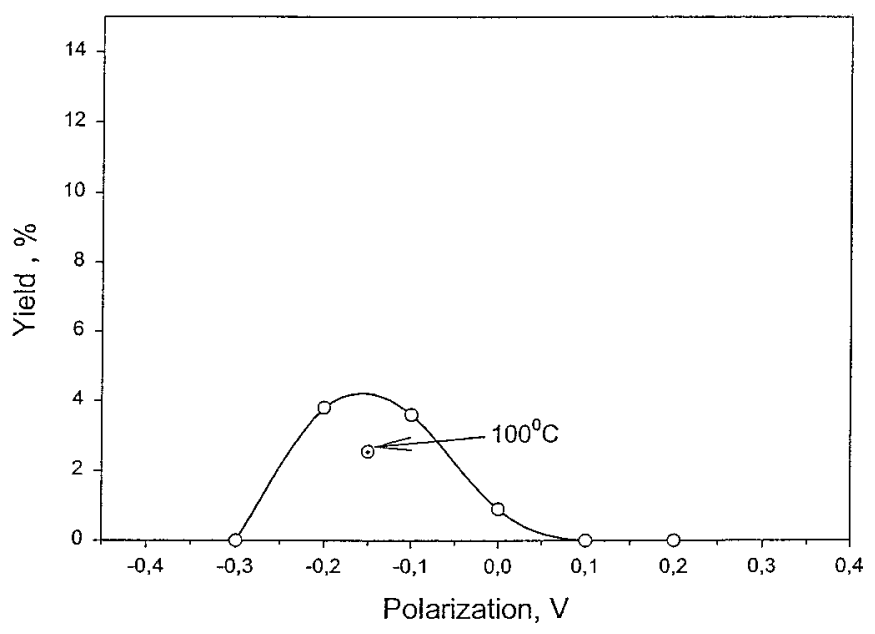

Figure 3. Dependence of $\mathrm{C}_{2} \mathrm{H}_{2}$ yield on polarization obtained in $\left(\mathrm{CH}_{4}, \mathrm{O}_{2}\right.$, $\mathrm{Ar}), \mathrm{Pt} / \mathrm{PBI}-\mathrm{H}_{3} \mathrm{PO}_{4} / \mathrm{Pt},\left(\mathrm{H}_{2}, \mathrm{Ar}\right)$ fuel cell at $135^{\circ} \mathrm{C}$.

It can be concluded that the presence of hydrogen in the reactant mixture at low temperature increases the $\mathrm{C}_{2} \mathrm{H}_{2}$ yield of OCM. Therefore, the most probable explanation of the unusual $\mathrm{CH}_{4}$ $\rightarrow \mathrm{C}_{2} \mathrm{H}_{2}$ conversion in the present study is based on proton conductivity of the Pt catalyst support. It can be assumed that there is an $\mathrm{H}^{+} \rightleftharpoons \mathrm{H}_{\text {ads }}$ equilibrium at the three-phase boundary of the catalyst, and this equilibrium is a source of the $\mathrm{H}_{\text {ads }}$ active centers for the $\mathrm{CH}_{4} \rightarrow \mathrm{C}_{2} \mathrm{H}_{2}$ conversion.

Dependence of the $\mathrm{C}_{2} \mathrm{H}_{2}$ yield on polarization is given in Fig. 3 . It can be seen that the $\mathrm{CH}_{4} \rightarrow \mathrm{C}_{2} \mathrm{H}_{2}$ catalytic reaction can be electrochemically promoted at negative polarization and exhibits a clear "volcano-type" promotion behavior. ${ }^{4}$ This means that there is a maximum promotion effect at a polarization of $-0.15 \mathrm{~V}$, or $0.45 \mathrm{~V}$ catalyst potential vs. the hydrogen electrode $\left(3.8 \% \mathrm{C}_{2} \mathrm{H}_{2}\right.$ yield). The catalytic rate enhancement ratio, $r\left(\mathrm{C}_{2}\right) / r_{\mathrm{o}}\left(\mathrm{C}_{2}\right)$ (Ref. 4), at this maximum is 4.2. It can also be seen from Fig. 3 that there is no $\mathrm{C}_{2} \mathrm{H}_{2}$ production at polarizations $\geqslant 0.1 \mathrm{~V}$ and $\leqslant-0.3 \mathrm{~V}$. The yield of $\mathrm{C}_{2} \mathrm{H}_{2}$ decreases with decreasing temperature. The value of $\lambda$ calculated for the case of maximum promotion effect was $7.9 \times 10^{3}$, i.e., $\lambda$ $\gg 1$. This means that the electrochemical promotion for the $\mathrm{CH}_{4}-\mathrm{C}_{2} \mathrm{H}_{2}$ route has an EPP nature.

Dependence of $\mathrm{CO}_{2}$ yield on polarization is given in Fig. 4. This



Figure 4. Dependence of $\mathrm{CO}_{2}$ yield on polarization obtained in $\left(\mathrm{CH}_{4}, \mathrm{O}_{2}\right.$, $\mathrm{Ar}), \mathrm{Pt} / \mathrm{PBI}-\mathrm{H}_{3} \mathrm{PO}_{4} / \mathrm{Pt},\left(\mathrm{H}_{2}, \mathrm{Ar}\right)$ fuel cell at $135^{\circ} \mathrm{C}$.

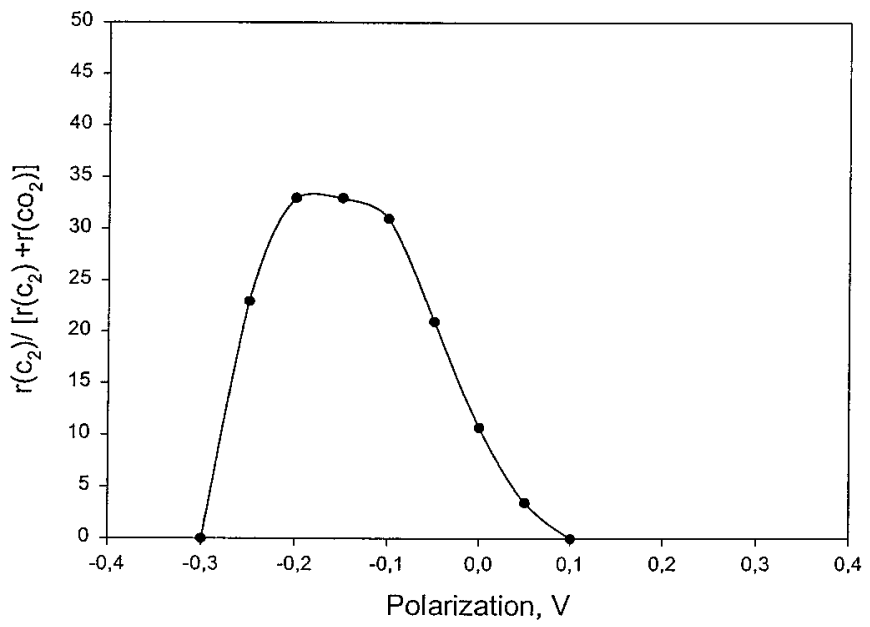

Figure 5. Dependence of $r\left(\mathrm{C}_{2}\right) /\left[r\left(\mathrm{C}_{2}\right)+r\left(\mathrm{CO}_{2}\right)\right]$ ratio on polarization obtained in $\left(\mathrm{CH}_{4}, \mathrm{O}_{2}, \mathrm{Ar}\right), \mathrm{Pt} / \mathrm{PBI}-\mathrm{H}_{3} \mathrm{PO}_{4} / \mathrm{Pt},\left(\mathrm{H}_{2}, \mathrm{Ar}\right)$ fuel cell at $135^{\circ} \mathrm{C}$.

dependence also shows a volcano-type behavior with maximum yield of $8.3 \%$ at $-0.15 \mathrm{~V}$, i.e., at the same potential as for $\mathrm{C}_{2} \mathrm{H}_{2}$ production. The catalytic rate enhancement ratio for $\mathrm{CO}_{2}$ production, $r\left(\mathrm{CO}_{2}\right) / r_{\mathrm{o}}\left(\mathrm{CO}_{2}\right)$, at this maximum is 1.1 , which means that this catalytic reaction is only slightly affected by the electrochemical polarization. This also means that the polarization affects the $\mathrm{C}_{2}$ selectivity more than the $\mathrm{CO}_{2}$ selectivity. Figure 5 shows the "volcanic" nature of the dependence of the ratio between $r\left(\mathrm{C}_{2}\right)$ and $r\left(\mathrm{C}_{2}\right)+r\left(\mathrm{CO}_{2}\right)$ with a maximum at $-0.2 \mathrm{~V}$. Similar to the $\mathrm{C}_{2} \mathrm{H}_{2}$ path, $\mathrm{CO}_{2}$ production is inhibited at very positive and very negative polarizations and decreases with a temperature decrease from 135 to $100^{\circ} \mathrm{C}$ (Fig. 4). The value of $\lambda$ calculated for the case of maximum promotion effect was $2.7 \times 10^{3}$, i.e., $\lambda \gg 1$, meaning that the electrochemical promotion for the $\mathrm{CH}_{4}-\mathrm{CO}_{2}$ route (as in the case of the $\mathrm{CH}_{4}-\mathrm{C}_{2} \mathrm{H}_{2}$ route) has an EPP nature.

The same potential of maximum promotion for both $\mathrm{C}_{2} \mathrm{H}_{2}$ and $\mathrm{CO}_{2}$ paths shows that polarization probably has the same effect on the rate-determining stages of these paths. It would therefore be useful to review the published data on electrochemical conversion of methane. Since the 1960s there have been many publications on the electrocatalytic oxidation of methane in connection with the development of phosphoric acid fuel cells. ${ }^{18}$ This reaction was mainly studied on platinum and platinum group metal catalysts. In most of the studied cases there was a complete electrocatalytic oxidation of methane to $\mathrm{CO}_{2} \cdot{ }^{18}$ It has been shown that the rate-determining step of this reaction is dissociative chemisorption of methane at the catalyst-electrolyte interface. Moreover, it has been found that on a Pt-black catalyst in $4.3 \mathrm{M} \mathrm{HClO}_{3}$ at $65^{\circ} \mathrm{C}$ the maximum amount of methane is adsorbed at $0.3 \mathrm{~V} v s$. the standard hydrogen electrode (SHE). ${ }^{23}$

The only studied electrochemical system that provided the oxidative coupling of methane was a high-temperature fuel cell with zirconia-based solid electrolytes. ${ }^{18}$ The effect of polarization on the oxidative methane coupling in the $\mathrm{CH}_{4}, \mathrm{O}_{2} / \mathrm{Ag} / \mathrm{YSZ} / \mathrm{Pt} / \mathrm{O}_{2}$ fuel cell at $800^{\circ} \mathrm{C}$ was studied by Seimanides and Stoukides. ${ }^{24}$ They have shown that "oxygen pumping" at positive polarization promotes methane conversion to $\mathrm{CO}_{2}$ and that negative polarization slightly promotes the OCM to $\mathrm{C}_{2} \mathrm{H}_{4}$ and $\mathrm{C}_{2} \mathrm{H}_{6}$, therefore promoting $\mathrm{C}_{2}$ selectivity.

In order to explain similarities and differences in the electrochemical promotion of methane conversion in $\mathrm{CH}_{4}, \mathrm{O}_{2} / \mathrm{Pt} / \mathrm{PBI}-\mathrm{H}_{3} \mathrm{PO}_{4} / \mathrm{Pt}, \mathrm{H}_{2}$, and $\mathrm{CH}_{4}, \mathrm{O}_{2} / \mathrm{Ag} / \mathrm{YSZ} / \mathrm{Pt} / \mathrm{O}_{2}$ fuel cell systems we should compare the open-circuit potentials of the $\mathrm{Pt}$ and $\mathrm{Ag}$ catalysts in these systems. In the present study for the Pt catalyst it was $0.6 \mathrm{~V} v s$. the hydrogen electrode and in Ref. 24 it was 


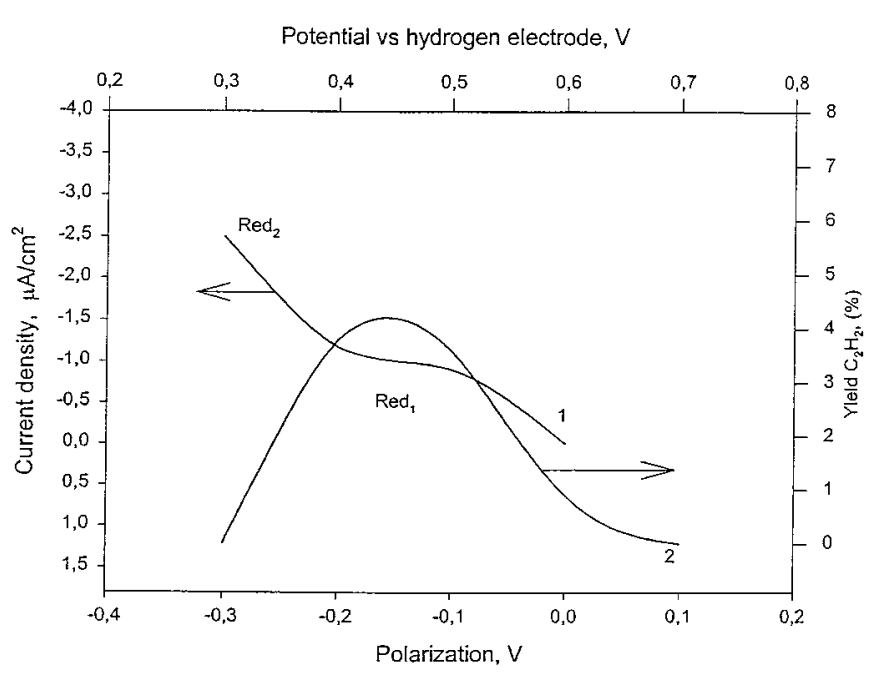

Figure 6. Steady-state voltammetric curve (1) obtained at Pt catalyst and dependence of $\mathrm{C}_{2} \mathrm{H}_{2}$ yield on polarization (2) obtained in $\left(\mathrm{CH}_{4}, \mathrm{O}_{2}, \mathrm{Ar}\right)$, $\mathrm{Pt} / \mathrm{PBI}-\mathrm{H}_{3} \mathrm{PO}_{4} / \mathrm{Pt},\left(\mathrm{H}_{2}, \mathrm{Ar}\right)$ fuel cell at $135^{\circ} \mathrm{C}$.

$-0.45 \mathrm{~V} v$ s. the oxygen electrode, i.e., approximately $0.6-0.8 \mathrm{~V}$ against the hydrogen electrode. Considering the value of the potential of the maximum $\mathrm{CH}_{4}$ adsorption, i.e., $0.3 \mathrm{~V}$ vs. $\mathrm{SHE}^{23}$ the catalyst potentials in both fuel cells should be moved in the negative direction in order to achieve this maximum. The data obtained in this work on OCM and $\mathrm{C}_{2}$ selectivity is in agreement with this assumption. Moreover, the much stronger promotion effect in the $\mathrm{CH}_{4}, \mathrm{O}_{2} / \mathrm{Pt} / \mathrm{PBI}-\mathrm{H}_{3} \mathrm{PO}_{4} / \mathrm{Pt}, \mathrm{H}_{2}$ system can be explained on the basis of the difference in the current carriers in this system and the $\mathrm{CH}_{4}, \mathrm{O}_{2} / \mathrm{Ag} / \mathrm{YSZ} / \mathrm{Pt} / \mathrm{O}_{2}$ fuel cell, protons and oxide ions, respectively.

A steady-state voltammetric curve obtained at the Pt catalyst (curve 1) and $\mathrm{C}_{2} \mathrm{H}_{2}$ yield vs. polarization dependence (curve 2) are given in Fig. 6. It can be seen that the polarization range of the $\mathrm{C}_{2} \mathrm{H}_{2}$ production (0.3-0.6 $\mathrm{V} v s$. the hydrogen electrode) is the potential range of the reduction wave $\operatorname{Red}_{1}$. This wave has a limiting current plateau at around $1 \mu \mathrm{A} / \mathrm{cm}^{2}$ at the potentials of the maximum promotion effect. It has been found ${ }^{25}$ that during the electrochemical reduction of $\mathrm{H}^{+}$in $0.1 \mathrm{M} \mathrm{H}_{3} \mathrm{PO}_{4}$ at $25^{\circ} \mathrm{C}$ at a $\mathrm{Pt}$ rotating disk electrode, covered by PBI thin film, so-called strongly adsorbed hydrogen is produced in the region of 0.2-0.4 V vs. the reversible hydrogen electrode. It is natural to assume that wave $\operatorname{Red}_{1}$ is caused by the electrochemical production of strongly adsorbed hydrogen. The combination of the maximum $\mathrm{CH}_{4}$ adsorption and electrochemical production of the Pt-H active sites (in the same potential region), which stabilize $\mathrm{C}_{2}$ products, can provide a strong promotion effect at the $\mathrm{CH}_{4}, \mathrm{O}_{2} / \mathrm{Pt} / \mathrm{PBI} / \mathrm{H}_{3} \mathrm{PO}_{4}$ boundary. In the case of the $\mathrm{CH}_{4}, \mathrm{O}_{2} / \mathrm{Ag} / \mathrm{YSZ} / \mathrm{Pt} / \mathrm{O}_{2}$ fuel cell, this effect is much weaker because of the absence of the proton current carriers in the solid electrolyte.

It was found that electrochemical conversion of $\mathrm{CH}_{4}$ into $\mathrm{CO}_{2}$ proceeds through the formation of the so-called O-type products of the dissociative adsorption of methane, i.e., $\equiv \mathrm{COH},-\mathrm{CHO}^{18}$ This means that in this case parameters of the oxygen adsorption should play an important role in the kinetics of the methane conversion. Positive polarization of the $\mathrm{Ag}$ catalyst ${ }^{24}$ probably provides the optimum potential for the oxygen adsorption at the catalyst-gas interface.

The experimental data is in good agreement with our assumption about the EPP nature of the electrochemical promotion in the $\mathrm{CH}_{4}, \mathrm{O}_{2} / \mathrm{Pt} / \mathrm{PBI}-\mathrm{H}_{3} \mathrm{PO}_{4} / \mathrm{Pt}, \mathrm{H}_{2}$ system. It is also in agreement with

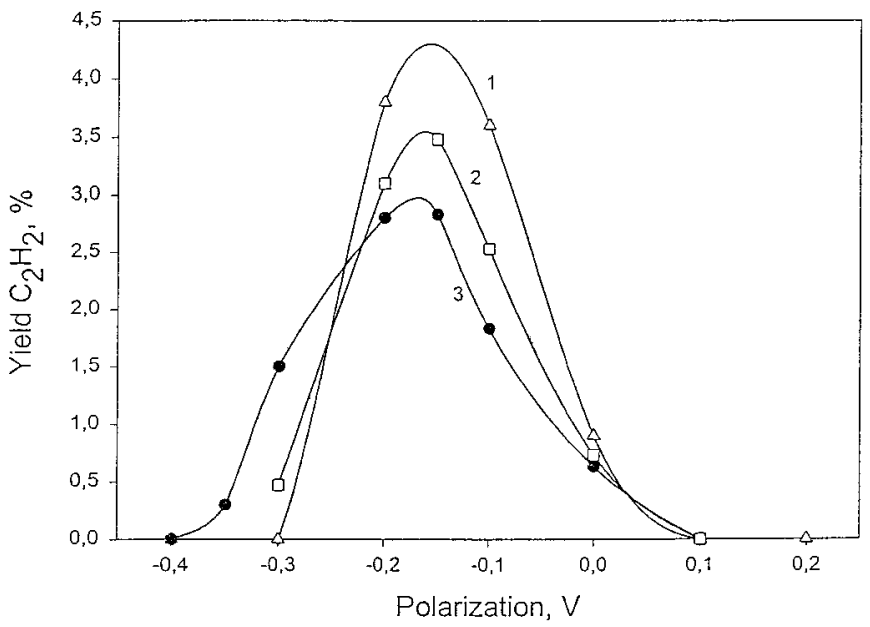

Figure 7. Dependence of electrochemical promotion on the partial pressure of hydrogen at the counter electrode obtained in $\left(\mathrm{CH}_{4}, \mathrm{O}_{2}, \mathrm{Ar}\right)$, $\mathrm{Pt} / \mathrm{PBI}-\mathrm{H}_{3} \mathrm{PO}_{4} / \mathrm{Pt},\left(\mathrm{H}_{2}\right.$, Ar) fuel cell at $135^{\circ} \mathrm{C}$ (1) 100 vol \%; (2) 50 vol \%; (3) $0 \mathrm{vol} \% \mathrm{H}_{2}$ ).

the assumption that through the reversible $\mathrm{e}^{25}$ electrochemical production of Pt-H sites we can create a new OCM route for catalytic $\mathrm{CH}_{4}$ oxidation.

The experimental data given in Fig. 7 are also in agreement with the assumption about the EPP nature of the promotion of $\mathrm{C}_{2} \mathrm{H}_{2}$ production. Reversibility of the $\mathrm{H}^{+} \leftrightarrows \mathrm{H}_{\text {ads }}$ electrochemical reaction means that this reaction proceeds under diffusion control. Therefore, by changing the $\mathrm{H}^{+}$concentration gradient across the PBI electrolyte we should affect the $\mathrm{H}^{+}$diffusion rate and in this way the electrochemical $\mathrm{H}^{+}$reduction rate and the rate of OCM. As can be seen from Fig. 7, the zero hydrogen pressure at the counter electrode, which should provide a lower $\mathrm{H}^{+}$concentration gradient across the electrolyte, also provides a weaker promotion effect on the methane conversion into $\mathrm{C}_{2} \mathrm{H}_{2}$.

\section{Conclusions}

The possibility of creation of a new OCV route for catalytic $\mathrm{CH}_{4}$ oxidation by the electrochemical production of $\mathrm{Pt}-\mathrm{H}$ centers at the Pt-PBI $\left(\mathrm{H}_{3} \mathrm{PO}_{4}\right)$-gas boundary has been demonstrated.

It was shown that Pt catalyst activity and selectivity toward the $\mathrm{CH}_{4} \rightarrow \mathrm{C}_{2} \mathrm{H}_{2}$ reaction can be electrochemically promoted with the maximum promotion effect at $-0.15 \mathrm{~V}$.

The nature of electrochemical promotion was discussed. The conclusion was made that there are three different types of electrochemical promotion depending on values of faradaic current $(I)$ and $\lambda$

1. The electrochemical promotion effect is the charge-induced (electrostatic) change of the strength of chemisorptive bonds at the catalyst-reactant interface (CI-effect). The CI-effect is characterized by $I=0$. Charging of the electric double layer at the catalystsupport interface is the only result of the polarization of the catalyst. $\Delta \Psi \neq 0$ and $\Delta \Phi \neq \eta$.

2. The electrochemical promotion effect is induced by the electrochemical production of the catalyst promoters (EPP-effect). I $\neq 0 ; \lambda \gg 1 ; \Delta \Psi \approx 0$, and $\Delta \Phi \approx \eta$.

3. The case of electrocatalysis is when reactant (or reactants) of a catalytic reaction is oxidized or reduced electrochemically. $I \neq 0$, $\lambda \approx 1$.

The EPP nature of the electrochemical promotion of the $\mathrm{CH}_{4}$ $\rightarrow \mathrm{C}_{2} \mathrm{H}_{2}$ catalytic reaction was demonstrated $(\lambda \gg 1)$. 


\section{Acknowledgments}

This investigation was supported by the Danish Research Councils ICAT, project no. 9702636.

The Technical University of Denmark assisted in meeting the publication costs of this article.

\section{References}

1. C. Wagner, Adv. Catal., 21, 323 (1970).

2. C. G. Vayenas, S. Bebelis, and S. Ladas, Nature (London), 343, 625 (1990).

3. J. Pritchard, Nature (London), 343, 592 (1990).

4. C. G. Vayenas, M. M. Jakis, S. I. Bebelis, and S. G. Neophytides, in Modern Aspects of Electrochemistry N29, J. O'M. Bockris, B. E. Conway, and R. E. White, Editors, pp. 57-202, Plenum Press, New York (1996).

5. C. G. Vayenas and S. Bebelis, Catal. Today, 51, 581 (1999).

6. S. Bebelis, M. Makri, A. Buekenhoudt, J. Luyten, S. Brosda, P. Petrolekas, C Pliangos, and C. G. Vayenas, Solid State Ionics, 129, 33 (2000).

7. R. M. Lambert, A. Palermo, F. J. Williams, and M. S. Tikhov, Solid State Ionics, 136-137, 677 (2000).

8. V. D. Belyev, T. I. Politova, and V. A. Sobyanin, Solid State Ionics, 136-137, 721 (2000).

9. J. Poppe, S. Völkening, A. Schaak, E. Schütz, J. Janek, and R. Imbihl, Phys. Chem. Chem. Phys., 1, 5241 (1999).

10. I. S. Metcalfe, J. Catal., 199, 247 (2001).
11. I. S. Metcalfe, J. Catal., 199, 259 (2001)

12. G. Fóti, O. Lavanchy, and C. Comninelis, J. Appl. Electrochem., 30, 1223 (2000).

13. L. Ploese, M. Salazar, B. Gurau, and E. S. Smotkin, Solid State Ionics, 136-137, $713(2000)$

14. I. M. Petrushina, V. A. Bandur, F. Cappeln, and N. J. Bjerrum, J. Electrochem. Soc., $147,3010(2000)$

15. R. B. Anderson, Experimental Methods in Catalytic Research, Academic Press, New York (1968)

16. L. Qingfeng, X. Gang, H. A. Hjuler, R. W. Berg, and N. J. Bjerrum, J. Electrochem. Soc., 141, 3114 (1994).

17. L. Qingfeng, H. A. Hjuler, and N. J. Bjerrum, J. Appl. Electrochem., 31, 773 (2001), and references cited therein.

18. Y. Amenomiya, V. I. Birss, M. Goledzinowski, J. Galuszka, and A. R. Sanger, Catal. Rev. - Sci. Eng., 32(3), 163 (1990)

19. L. Guczi, R. A. Van Santen, and K. V. Sharma, Catal. Rev. - Sci. Eng., 38(2), 249 (1996).

20. I. K. Weissermel and H. J. Arpe, Industrial Organic Chemistry, 2nd ed., Verlag Chemie, Weinheim (1993).

21. I. Vedrenne, J. Saint-Just, A. Ben Hadid, and G. M. Come, Catal. Today, 6, 381 (1990)

22. C. Liu, R. Mallinson, and L. Lobban, J. Catal., 179, 326 (1998)

23. L. W. Niedrach, J. Electrochem. Soc., 113, 645 (1966).

24. S. Seimanides and M. Stoukides, J. Electrochem. Soc., 133, 1535 (1986).

25. S. K. Zecevic, J. S. Wainright, M. H. Litt, S. Lj. Gojkovic, and R. F. Savinell, J. Electrochem. Soc., 144, 2973 (1997). 